\title{
Gateway to the real world, industrial training: dilemmas and problems
}

\author{
Ayşe Baş Collins* \\ Bilkent University, Ankara, Turkey
}

Received 8 August 2000; accepted 4 January 2001

\begin{abstract}
In today's competitive society, students are faced with a selective job market which places premium on experience. Hands-on experience cannot be imparted through lectures. It can only be gained through direct activity, either laboratory or real world confrontation. Laboratory learning is clinical, whereas, real-world confrontation, known as industrial training or internship, affords students a first hand glimpse of reality. There is no substitution for the "sting of battle". This paper examines stakeholders' reactions to the university level "industrial training" program and its success in providing a realistic workplace experience. The study examined the structure of the "industrial training system" (ITS), its strengths and weaknesses, and what can be done to improve the system. (C) 2001 Elsevier Science Ltd. All rights reserved.
\end{abstract}

Keywords: Internship; Industrial training; Turkish hospitality training

\section{Introduction}

In very simple terms "internship" is a "bridge" from classroom to workplace. It is an opportunity to test skills, interests and career choices in real work situations while obtaining an edge on "inexperienced" job market competitors (Neuman, 1999). For some, it is "only" a requirement to complete their university study. Still others see internship as an opportunity to network, to learn new fields, or gain work experience (Seymore II \& Higham, 1996). Internship is not an optional enhancement to academic record, but an essential collegiate experience component.

Various research view internship programs from the perspective of students, schools and organizations. It is essential to update the internship programs and account for changed expectations. Students, accordingly, see internship as a credible means to land that first job (Cannon \& Arnold, 1998). Hite and Bellizi (1986) found that students view internships as valuable learning experience, for which they should receive academic credit, financial compensation, and earn a grade. They also feel that internships are more valuable than case

*Corresponding author. Hosdere cad., Cankaya Evleri, D Blok, Daire 1, Yukari Ayranci 06550, Ankara, Turkey. Tel.: +90-312-2905043; fax: +90-312-266-4607.

E-mail address: collins54@hotmail.com (A.B. Collins). teaching, that formal training should be at the beginning of internships and direct supervision present throughout. Finally, students feel that internships may result in employment. Students without practical experience realize that they have a disadvantage when compared to those with internship experience.

From the employer's perspective, it is a "golden opportunity to try before buying" students they might wish to recruit after graduation (Neuman, 1999; CatesMcIver, 1999). If employed, interns require less training and less time adjusting, than do non-interns. Interns learn quickly and represent flexible economic resources (Nevett, 1986; Pianko, 1996). Some organizations could not operate without interns due to funding shortages. Some small firms see internship as a source of inexpensive labor (Miner \& Crane, 1995). Busby, Brunt and Baber (1997) found that with late bookings and demand uncertainties, tour operators utilize interns as a flexible human resource.

Universities and colleges devote a great deal of energy acquiring internship positions. Placement officers should encourage students to report information regarding their employers' internship programs. Further, companies involved in partnering with colleges, through philanthropy, contracts and special projects, should be encouraged to use pools of former qualified interns to fill employment needs. Additionally, company consortia and industry groups should be encouraged to support 
internship programs and disseminate information on successful programs and interns. This constitutes good advertising for university and college programs.

The essential point is that internships offer excellent return to all parties involved (Knouse, Tanner, Harris, \& Elizabeth, 1999). This paper examines stakeholdersinterns', university authorities' and sector representatives' reactions to the university level "industrial training" program and its ability to impart workplace experience. The following research questions were explored: (1) What is the structure of the "industrial training system" (ITS)? (2) How is this system perceived in terms of strengths and weaknesses? and (3) What recommendations can be made to improve the system?

\section{Methods}

\subsection{Study site}

As in most countries, the Turkish tourism industry is in its infancy. Throughout the period 1950-1979, Turkey had relatively little formal tourism education beyond the secondary level. However, now in the year 2000, there are 53 two-year schools offering associate or certificate programs in tourism to 14,419 students and 14 four-year institutions offering tourism bachelor degree programs to 7102 students. Statistics show that 5 percent of the tourism work force possess higher education degrees (National Statistics, 1999). The tourism educational system is experiencing growing pains and problems as it defines its expanding role.

The study was conducted at Bilkent University, School of Tourism and Hotel Management located in Ankara, Turkey and various establishments throughout Turkey where students are required to complete 75 days of industrial training during the third year spring or fourth year fall semesters.

\subsection{Measures and sampling}

Both quantitative and qualitative methods were employed for data collection throughout 1999-2000 academic year. Industrial training effectiveness was assessed from three perspectives: students, organizations and the university. The sub-samples were:

(1) Student participants: The research was conducted with (all) 113 students, of whom 63 had completed industrial training and 50 were in industrial training at the time of the study.

(2) Organization participants: The research was conducted at nine five-star hotels, three restaurants, and three catering centers. Within these organizations, 76 professionals, who supervised these students, were included. The breakdown was as follows: eight human resources managers, seven executive chefs, nine front office managers, six front office assistants, five purchasing assistants, six banquet managers, seven service managers, seven sales managers, seven food and beverage managers, seven house-keeping managers and seven accounting managers.

(3) University participants: six Industrial Training Coordination Office (ITCO) staff consisting of two assistant chairs, three assistant directors and one internship coordinator.

Data were gathered through four instruments: questionnaires, interview schedules, critical incident forms and material analysis. Three sets of questionnaires and critical incident forms were distributed to all subject groups. Moreover, interviews were conducted with 40 students, 30 organization and all school participants. The data were subjected to quantitative (descriptive) and qualitative (content) analysis. Results were integrated with the information from written documents, such as industrial training documents.

\section{Results}

Most students (92 percent) define ITS as "combination of academic knowledge", "practical experience" and "opportunity to know business environment". Only 8 percent define it as a "must for passing and graduating". A majority of ITCO staff ( 89 percent) define ITS as "practical experience" and "an opportunity to define career goals". Whereas, 11 percent regard ITS as decreasing student anxiety towards business life. Organizations view ITS as an "opportunity to select future qualified personnel" (32 percent), "meeting temporary personnel needs with an inexpensive work force" (30 percent), "increasing intern's performance level" (27 percent) and "cooperation between educational institutions and hospitality sector" (11 percent).

Regarding remuneration during industrial training, interns were provided meals (46 percent), salary (19 percent), transportation ( 8 percent), medical services ( 8 percent), insurance ( 6 percent), accommodation (5 percent), social activities (5 percent) and 3 percent were not offered any of these.

Data reveal that most of the students (87 percent) were given orientation by the organizations. However, during the internship most of the students (58 percent) complained that they were not given enough training. Training was given in departmental operations, hygiene, service and kitchen methods, bomb and fire emergency procedures. Results show that successful internship periods present a possibility of being hired by the same company after graduation, as interns were recruited by 62 percent of participating organizations. 
Although there are complaints regarding the ITCO control and grading system, the majority of the participants rate ITS as successful, achieving its goals and beneficial to students. The control system is considered ineffective and interns believe that "university cannot view what interns are really learning by five-minute visits". Moreover, they state that these short visits decrease their motivation since they feel under pressure to prove performance in a short period.

Industrial training grading is based on three sources: project submittals, performance reports from organizations and school supervisors. Students complain that project grading breakdown is ambiguous. They believe that viewing the "project file" and "project report" are effective methods to evaluate the internship outcome. Moreover, more than half of the students consider the "presentation" portion of project submitted as ineffective although all these three methods are viewed effective by ITCO staff.

When students evaluate the role of their organizational supervisors regarding their skill improvement, they term this role as "outstanding" (13 percent; $n=15)$, "very sufficient" (42 percent; $n=48$ ) and "sufficient" (24 percent; $n=27)$. The remaining (21 percent; $n=23$ ) found organizational supervision as "inadequate." Students rate authority delegated them as "very high" (6 percent; $n=7$ ), "high" (8 percent; $n=9$ ), "above moderate" (39 percent; $n=44)$, "moderate" (25 percent; $n=28)$, "low" (10 percent; $n=11$ ), and "very low" (12 percent; $n=14$ ). Participating organizations state, after training interns, that they delegate controlled responsibility. This permits interns to handle jobs in their absence.

Factors that decrease the motivation of interns are no payment, lack of communication between employees, an uncomfortable and hectic work environment, negative supervisor attitude, lack of responsibility and limited opportunities. The majority of students complain about "lack of job description" (32 percent; $n=36$ ), "strict rules" (27 percent; $n=31$ ), "slave work" (23 percent; $n=26$ ), "not enough chance to learn" (10 percent; $n=11)$, and "negative behavior of both employers and colleagues" ( 8 percent; $n=9$ ).

Regarding the human relations during industrial training, most students ( 83 percent) view the relationship with the hotel personnel as very professional and helpful. Moreover, most of the students (86 percent) state that guests consider interns with the same attitude as other hotel personnel. Department managers mention both positive and negative points about the interns. They emphasize that students with a foreign language are "very beneficial". They tend to satisfy foreign guests, especially in the "front office department". It is also mentioned that, through a second foreign language, interns may manage international business dealings.

\section{Discussion}

In the last two decades, the tourism industry has seen tremendous growth. With this growth, human resources have become increasingly important as a means of achieving business success. Under-educated labour became a problem in respect of both cost and final product. Many studies have been conducted on tourism education programs. These studies found that education should be business oriented, relevant to the industry and should be supported by incentive industrial training programs. Shortt (1992) claims that, education in tourism must meet the needs of the industry through practical facilities and first class academic staff. Similarly, Gunn (1998) claims that there is no single tourism education program model that can be applied for all institutions. They should determine for whom the program is intended and what is expected from it. Moreover, programs should provide students with needed tools and educate them to take responsibility in future work life, thus bridging the gap, as one of the findings of this study.

When considering the research and pertinent literature, certain recommendations can be made to better the current industrial training programs and meet the stakeholder's expectations.

The ITCO acts as the "middle-man" between the organisations and students. It should employ adequate number and quality of staff to assist students. The role of this office should be made clear to each stakeholder: interns, the school and organizations. Orientation should be given to interns explaining the aims and importance of industrial training, related laws, rules/ regulations and methods to handle problems. Above all other things, interns should understand that they represent their department during internship and that therefore, any misunderstanding may spoil employment opportunities for graduates and future students.

The ITCO should have a professional control system. The work environment structure should be under the constant monitoring of a training coordinator. The coordinator's main function should assure that the industrial training experience improves students' skills and abilities and protects students against unexpected situations. The training coordinator should work with the orgaizations to plan intended use and compensation of interns. This should include positions and responsibility given to interns, department rotation, working hours, meals, transportation, uniforms and accommodations. Even salary, social security insurance and health insurance should be considered.

Organizations should provide orientation to assure that interns are aware of expectations and what they should expect from the organization (Harris 1994). These conditions should result in a legal contract between the school and the organization. Reviews 
should be performed which would allow the coordinators to evaluate organizations' performance in meeting ITS goals. Failure to meet minimal levels would dictate intern placement in other oganizations. The program must be mutually beneficial. More cooperation between the school and industry is necessary and should be developed. This may be achieved by "appointment of senior practitioners as external examiners, the use of advisory panels and visiting lecturers" to enhance understanding between organizations and universities (Busby et al. 1997).

The ITCO should organise mid-term intern reviews. These meetings would provide interns information regarding school events and allow the school to review intern progress. Further, interns should be encouraged to offer feedback regarding the organizations and overall industrial training program.

Lastly, the industrial training grading system should be renewed and communicated to the students. Each component, namely internship performance, industrial training file completion, project and presentation of the project should be weighted accordingly. There is no better teacher than experience to allow students to "touch the stove", so to speak, enhance their formal learning curve and, in most instances, that curve turns up when industrial training is implemented. Education was never meant to be isolated in an Ivory Tower, it must be embraced by those that are taught as relevant to life.

\section{References}

Busby, G., Brunt, P., \& Baber, S. (1997). Tourism sandwich placements: An appraisal. Journal of Tourism Management, 18, $105-110$.

Cannon, J. A., \& Arnold, M. J. (1998). Student expectations of collegiate internship programs. Journal of Education for Business, 73(4), 202.

Cates-McIver, L. (1999). Internships and co-op programs, a valuable combination for collegians. Black Collegian, 30, 84.

Gunn, C. A. (1998). Issues in tourism curricula. Journal of Travel Research, 36(4), 74-77.

Harris, J. K. (1994). Faculty internship: Bridging the gap between education and industry. Forum, 6(4), 68-72.

Hite, R., \& Bellizi, R. (1986). Student expectations regarding collegiate internship programs in marketing. Journal of Marketing Education, 8(41), 49.

Knouse, S. B., Tanner, J. T., Harris, \& Elizabeth, W. (1999). Internships: Save disquieting findings. Journal of Employment Counselling, 36(1), 35.

Miner, J. B., \& Crane, D. P. (1995). Human Resources Management. New York: Harper Collins.

National Statistics (1999). Ankara: Government Printing Office.

Neuman, H. (1999). Internships. Career World, 27(6), 16.

Nevett, T. (1986). Internship problems are not endemic to the United States. Marketing Educator, 5(3), 3.

Pianko, O. (1996). Power internships. Management Review, 85(12), 31-33.

Seymore II, D., \& Higham, M. T. (1996). The access guide to international affairs internships. Washington, DC: Access.

Shortt, G. (1992). Education and training for the Indonesian tourism industry. Hospitality \& Tourism Educator, 5(1), 79. 